\title{
Partisipasi Wanita Penjual Kue Tradisional Dalam Meningkatkan Pendapatan Keluarga Menurut Perspektif Ekonomi Islam
}

\author{
Beti Mulu \\ Institut Agama Islam Negeri Kendari \\ E-mail:betimulu@yahoo.com
}

\begin{abstract}
This study aims to analyze: (l) Knowing the amount of women's income contribution to selling traditional cakes to family income, (2) Knowing the motivation of traditional cake-selling women; do the job of selling traditional processed foods doing the job of selling traditional cakes, and (3) To find out the participation of women traditional cake sellers in increasing family income according to the Islamic economic perspective. Data collection techniques were carried out in two ways, namely primary data through direct interviews using questionnaires to sample respondents and secondary data obtained from literature and literature compilation results. Data that had been collected was processed using qualitative and quantitative descriptive statistical analysis.

The results of the study concluded that the amount of income of women selling traditional cakes is Rp. 7,200,000 or an average of Rp. 1,435,000, husband's income is Rp. $12,000,000$ or an average of $\mathrm{Rp} .2,400,000$, while the income of other family members is Rp. 3,700,000 or an average of Rp. 740,000. From this description, it can be seen that the total income of the family of traditional cake-making women in Wawonggole Village, Unaaha District, Konawe Regency is Rp. 22,900,000 or an average of Rp. 4,275,000. With the contribution of women's business income, traditional cake sellers have a total family income of 31.44\%. Motivation of female respondents or housewives to make and sell traditional cakes is to increase family income and to spend free time with positive activities. The participation of women traditional cake sellers in an effort to increase their family's income and help with economic needs is a good business and in line with Islamic shari'a because it is done with good effort and intention, as long as the wife does not violate the Shari'ah, namely not leaving her obligations in managing the house stairs to help her husband. in general, a woman's business as a traditional cake seller to help improve the family's economy may be done because it does not conflict with the principles of Islamic Economics.
\end{abstract}

Keywords: Women's Participation, Family Income Contribution, and Islamic Economy.

\begin{abstract}
Abstrak
Penelitian ini bertujuan untuk menganalisis: (l) Mengetahui besarnya kontribusi pendapatan wanita pada kegiatan menjual kue tradisional terhadap pendapatan keluarga, (2) Mengetahui motivasi wanita penjual kue tradisiona; melakukan pekerjaan menjual makanan olahan tradisional melakukan pekerjaan menjual kue tradisional, dan (3) Untuk mengetahui partisipasi wanita penjual kue tradisional dalam meningkatkan pendapatan keluarga menurut perspektif ekonomi Islam. Teknik pengumpulan data dilakukan dengan dua cara, yaitu data primer melalui wawancara langsung
\end{abstract}


menggunakan kuesioner terhadap responden sampel dan data sekunder diperoleh dari hasil kompilasi literatur dan kepustakaan.. Data yang telah dikumpulkan, diolah dengan menggunakan analisis statistik deskriptif kualitatif dan kuantitaif.

Hasil penelitian menyimpulkan bahwa besarnya pendapatan wanita penjual kue tradisional adalah sebesar Rp. 7.200 .000 atau dengan rata-rata sebesar Rp. 1.435.000, pendapatan suami adalah sebesar Rp. 12.000 .000 atau dengan rata-rata sebesar Rp. 2.400.000, sedangkan pendapatan anggota keluarga lainnya adalah sebesar Rp. 3.700 .000 atau rata-rata Rp. 740.000. Dari uraian tersebut dapat diketahui total pendapatan keluarga wanita pembuat kue tradisional di Kelurahan Wawonggole Kecamatan Unaaha Kabupaten Konawe adalah sebesar Rp. 22.900 .000 atau rata-rata Rp. 4.275.000. Dengan kontribusi pendapatan usaha wanita penjual kue tradisional terhadap total pendapatan keluarga yaitu 31,44\%. Motivasi responden wanita atau ibu rumah tangga untuk membuat dan menjual kue tradisional adalah untuk menambah pendapatan keluarga dan untuk mengisi waktu luang dengan kegiatan positif. Partisipasi kaum wanita penjual kue tradisional dalam upaya meningkatkan pendapatan keluarganya dan membantu kebutuhan ekonomi merupakan usaha yang baik dan sejalan dengan syari'at Islam karena dilakukan dengan usaha dan niat yang baik, selama istri tidak melakukan pelanggaran syari'at yaitu tidak meninggalkan kewajibannya dalam mengatur rumah tangga untuk membantu suaminya. secara umum, usaha wanita sebagai penjual kue tradisional untuk membantu meningkatkan perekonomian keluarga boleh dilakukan karena tidak bertentangan dengan prinsip Ekonomi Islam.

\section{Kata Kunci : Partisipasi Wanita, Kontribusi Pendapatan Keluarga, dan Ekonomi} Islam.

\section{PENDAHULUAN}

Partisipasi wanita saat ini bukan sekadar menuntut persamaan hak tetapi juga menyatakan fungsinya mempunyai arti bagi pembangunan dalam masyarakat di Indonesia. Secara umum alasan perempuan bekerja adalah untuk membantu ekonomi keluarga. Keadaan perekonomian yang semakin tidak menentu, harga-harga kebutuhan pokok yang semakin meningkat, pendapatan keluarga yang cenderung tidak meningkat akan berakibat pada terganggunya stabilitas perekonomian keluarga. Kondisi inilah yang mendorong ibu rumah tangga yang sebelumnya hanya menekuni sektor domistik (mengurus rumah tangga), kemudian ikut berpartisipasi disektor publik dengan ikut serta menopang perekonomian keluarga. Sebagai tenaga kerja wanita dalam keluarga, umumnya ibu rumah tangga cenderung memilih bekerja di sektor informal. Hal ini dilakukan agar dapat membagi waktu antara pekerjaan dan keluarga (Handayani dan Artini, 2009).

Masyarakat Indonesia sedang mengalami perkembangan dari masyarakat yang agraris ke masyarakat industri. Dalam proses tersebut pengintegrasian wanita dalam pembangunan, terutama wanita dari golongan ekonomi lemah, yang berpenghasilan rendah perlu digalakkan, melalui peningkatan kemampuan dan keterampilan untuk melakukan kegiatankegiatan ekonomi produktif, dalam rangka memperluas kesempatan kerja dan menciptakan usaha bagi diri sendiri. Hal ini sangat perlu sebab wanita dari golongan masyarakat yang berpenghasilan rendah, umumnya melakukan peran ganda karena tuntutan kebutuhan untuk mempertahankan kelangsungan hidup 
bangsa. Wanita sebagai tenaga kerja ternyata memperoleh lapangan kerja yang lebih terbatas dari pria. Walaupun di Negara maju terdapat 70 persen wanita yang bekerja dilapangan kerja yang terorganisasi ternyata hanya terkonsentrasi pada 25 lapangan kerja, yang hanya dapat dimasuki oleh jumlah sedikit wanita (Fatmawati, 2011).

Perempuan sebagai warga negara maupun sebagai sumber daya manusia bagi pembangunan mempunyai hak, kewajiban dan kesempatan yang sama dengan kaum laki-laki di segala bidang kehidupan bangsa dan dalam segala kegiatan pembangunan. Hal yang demikian perlu terus diarahkan dan ditingkatkan sehingga dapat meningkatkan partisipasi bagi pembangunan bangsa sesuai dengan kodrat, harkat dan martabat sebagai perempuan (Sugiarti, 2008).

Peran perempuan dalam menopang ekonomi keluarga sangat penting, bahkan ada yang menjadi tulang punggung keluarga. Perjuangan yang mereka alami bukanlah takdir Allah SWT. Tak lain karena selama ini pemerintah sendiri tidak pernah memperhatikan hak-hak warganya. Khususnya para perempuan yang berdomisili di pedesaan. Mereka jarang mendapatkan pembinaan serta bantuan dari pemerintah, tak jarang posisi perempuan menjadi polemik di tengah masyarakat, ketika mereka harus bekerja untuk mempertahankan dapur supaya tetap mengepul. Bekerja serabutan akan dijalani, tidak peduli harus memeras keringat dan membanting tulang, seperti pada kelas pekerja buruh tani, pedagang sayur, penjahit dan lain-lain. Namun sayang, jasa perempuan dihargai jauh lebih rendah dari pada laki-laki, dengan anggapan bahwa kerja laki-laki lebih berat. Dengan begitu, posisi kaum lakilaki dianggap sebagai raja di dalam keluarga, masyarakat, organisasi, serta di tempat mereka bekerja, dan perempuan sebagai batur (pembantu), tetap kukuh dan tak tergoyahkan (Sobary, 1999).

Wanita dengan berbagai aktivitas kerja sehari-hari baik yang dilakukan secara terencana maupun tidak pada dasarnya mempunyai nilai ekonomis, terutama bila dikaitkan dengan pendapatan dalam usaha membantu keluarga. Peranan wanita khususnya dalam keinginan mencari nafkah bertujuan untuk meningkatkan kesejahteraan keluarga, oleh karena itu perlu dukungan masyarakat yang semakin tinggi terhadap perluasan kesempatan berkarya bagi wanita khususnya di pedesaan. Guna meningkatkan penghasilan, peran sertawanita dalam rumah tangga sangat diharapkan. Tenaga kerja wanita dalam usaha penetasan memegang peranan yang penting, karena dalam usaha penetasan dapat menyumbangkan pendapatan yang cukup besar (Utami dkk, 2012).

Dalam konteks pembangunan nasional, pemberdayaan perempuan berarti upaya menumbuh kembangkan potensi dan peran perempuan dalam semua dimensi kehidupan. Tujuan dari program permberdayaan perempuan, antara lain:

1. Meningkatkan kemampuan kaum perempuan untuk melibatkan diri dalam program pembangunan, sebagai partisipasi aktif (subjek) agar tidak sekedar menjadi objek pembagunan seperti yang terjadi selama ini;

2. Meningkatkan kemampuan kaum perempuan dalam kepemimpinan, untuk meningkatkan posisi tawarmenawar dan keterlibatan dalam setiap pembangunan baik sebagai perencana, pelaksana, maupun melakukan monitoring dan evaluasi kegiatan;

3. Meningkatkan kemampuan kaum perempuan dalam mengelola usaha skala rumah tangga, industri kecil maupun industri besar untuk menunjang peningkatan kebutuhan 
rumah tangga, maupun untuk membuka peluang kerja produktif dan mandiri;

4. Meningkatkan peran dan fungsi organisasi perempuan di tingkat lokal sebagai wadah pemberdayaan kaum perempuan agar dapat terlibat secara aktif dalam program pembangunan pada wilayah tempat tinggalnya (Nugroho, 2008).

Salah satu upaya pemerintah untuk mensejahterakan masyarakatnya adalah dengan meningkatkan pembangunan keseluruh lapisan daerah termasuk pembangunan yang dilakukan pada sektor pertanian di pedesaan. Karena dengan meningkatkan pembangunan pada sektor pertanian diharapkan dapat menambah devisa yang berasal dari sektor pertanian.Dalam proses meningkatkan pembangunan pada sektor pertanian peran anatara laki-laki dan perempuan bisa setara. Hal yang bertujuan agar kehidupan rumah tangga pada petani dapat bertahan (survive) dan memperlancar ekonomi rumah tangga, diperlukan keterlibatan perempuan dalam kegiatan ekonomi tidak terlepas dari keberhasilan pembangunan di semua bidang yang memberikan peluang bagi semua perempuan untuk mendapatkan pendidikan dan kesempatan berkarir yang semakin terbuka.Adapun motivasi utama wanita di pedesaan untuk bekerja pada umumnya disebabkan karena tuntutan ekonomi keluarga dan bertujuan untuk menambah pendapatan keluarga (Dina dkk dalam Majid, 2012).

Perbedaan peran perempuan dalam konsep Islam dan sekuler memang sangat signifikan, karena konsep dasar yang saling bertolak belakang. Peran perempuan dalam konsep sekuler selalu berorientasikan pada apa yang bisa dihasilkan dalam bentuk materi, seperti pendapatan, keterwakilan perempuan dalam parlemen dan lain sebagainya.Sedangkan dalam Islam sangat menghormati perempuan baik sebagai anggota keluarga dan anggota masyarakat (Dahlan, 1994).

Potensi yang dimiliki wanita untuk menopang ekonomi keluarga memang cukup besar. Namun demikian wanita tidak menonjolkan diri atau mengklaim bahwa mereka menjadi penyangga utama ekonomi keluarga. Wanita Indonesia terutama di perdesaan sebagai sumber daya manusia cukup nyata partisipasinya khususnya dalam memenuhi fungsi keluarga dan rumah tangga bersama pria (Lestari,dkk, 1997).

Seiring dengan sifat dasar manusia yang tidak pernah puas, peran perempuan dalam keluarga pun bisa berubah atau dalam hal ini bertambah, ia pun bisa ikut ber"usaha" layaknya seorang suami atau bapak didalam keluarga. Mereka bisa mempunyai usaha sendiri dengan tetap tidak melupakan status mereka sebagai ibu rumah tangga. Hal ini terjadi disebabkan karena adanya faktor-faktor yang mendukung sang ibu yang mendorongnya untuk memulai usaha tersebut, yang juga perlu dilihat nantinya adalah ada tidaknya keseimbangan yang terjadi pada mereka dengan kenyataan bahwa status mereka tetap sebagai ibu rumah tangga dan sebagai wanita pengusaha. Karena bisa terjadi ada perempuan yang kemudian berhasil dalam usahanya namun gagal dalam perannya sebagai ibu rumah tangga, atau sebaliknya ia gagal dalam usahanya tetapi perannya sebagai ibu rumah tangga dapat dijalaninya dengan baik. Dengan kata lain peran domestik (ibu rumah tangga murni) dan peran publik (ibu rumah tangga pengusaha), keduanya harus berjalan dengan baik. Lebih lanjut dijelaskan bahwa ibu rumah tangga mulai melakoni usaha karena adanya dorongan untuk dapat meningkatkan pendapatan keluarga mereka, sehingga keuangan keluarga tidak hanya menjadi tanggungan kepala keluarga dalam hal ini suami (Mulyati dan Setiawan, 2006). 
Dalam dunia kerja, saat ini semakin banyak wanita yang berpartisipasi dalam dunia kerja (ekonomi). Trend ini bukan hanya dijumpai di kota-kota besar saja, tetapi di daerah pedesaan, seperti di Kelurahan Wawonggole Kecamatan Unaaha, Kabupaten Konawe telah banyak wanita yang bekerja walaupun masih didominasi oleh kaum pria. Keputusan wanita atau istri untuk bekerja membawa konsekuensi dan tanggung jawab rangkap sebagai ibu rumah tangga dan sebagai pekerja khususnya menyangkut pembagian waktu untuk melakukan pekerjaan rumah tangga dan pekerjaan mencari nafkah.

Islam telah mengajarkan bahwa motivasi dan alasan bekerja adalah dalam rangka mencari karunia Allah SWT. Tujuan bekerja adalah untuk mendapatkan harta agar seseorang dapat memenuhi kebutuhanya, menikmati kesejahteraan hidup dan perhiasan dunia. Pekerjaan yang dilakukan tersebut haruslah pekerjaan yang halal agar aktifitas bekerja ini juga bernilai ibadah. Tentunya dalam pandangan Islam agar harta yang didapatkan dari bekerja tersebut menjadi kepemilikan yang sah. Bekerja bukan merupakan sebab mendapatkan harta melainkan perwujudan dari pelaksanaan perintah syara' (Sholahuddin, 2007).

Sebagaimana Firman Allah SWT dalam surat Al-Jumu'ah ayat 10 berikut :Artinya: "Apabila telah ditunaikan shalat, Maka bertebaranlah kamu dimuka bumi dan carilah anugrah dari Allah dan ingatlah Allah banyakbanyak supaya kamu beruntung". (Depag RI, Al-Quran dan Terjemahan, 2002).

Sumber daya manusia sangat penting dalam pembangunan, baik modal sumber daya pria maupun wanita. Salah satu alasan yang sangat fundamental untuk mengatakan demikian itu ialah bahwa baik untuk mengahadapi tuntutan tugas sekarang dan terutama untuk menjawab tantangan masa depan, pengembangan sumber daya manusia merupakan keharusan mutlak (Said, 2008).

Oleh karena itu Islam menganjurkan kepada pria dan wanita untuk bekerja. Pekerjaan merupakan salah satu sarana memperoleh rizki dan sumber kehidupan yang layak dan dapat pula bahwa bekerja adalah kewajiban dan kehidupan (Mursi, 1996).

Mempertimbangkan kondisi pentingnya peran wanita dalam menangkap peluang kerja, meningkatkan pendapatan, memberikan nilai tambah (added value) bagi kehidupan mereka dalam keluarga maupun dalam masyarakat, maka tujuan dari penelitian ini untuk: (1) Mengetahui besarnya kontribusi pendapatan wanita penjual kue tradisional terhadap pendapatan keluarga; (2) Mengetahui motivasi wanita penjual kue tradisional melakukan pekerjaan menjual kue tradisional; (3) Untuk mengetahui partisipasi wanita penjual kue tradisional dalam meningkatkan pendapatan keluarga menurut perspektif ekonomi Islam.

\section{TINJAUAN PUSTAKA}

\section{A. Partisipasi}

Partisipasi merupakan turut sertanya seseorang baik secara mental maupun fisik untuk memberikan sumbangan dalam proses pembuatan keputusan, terutama mengenai persoalanpersoalan keterlibatan pribadi yang bersangkutan untuk melaksanakan tanggung jawabnya dalam melakukan suatu hal (Winardi, 2002).

Seseorang ikut berpartisipasi bukan hanya sekedar ikut melakukan atau menjalankan saja tetapi karena alasan tertentu yaitu untuk memperoleh hasil yang nantinya akan mereka dapatkan berdasarkan besarnya pengorbanan yang telah dilakukan. Salah satunya adalah mendapatkan imbalan jasa, baik berupa makanan, upah uang tunai atau berupa material lainnya. Misalnya buruh dalam 
suatu perusahaan, mereka akan mendapat upah atau uang tunai apabila telah mengerjakan sejumlah pekerjaan tertentu dalam kurun waktu tertentu yang telah ditentukan (Tasbichah, 2015).

Partisipasi wanita saat ini bukan sekedar menuntut persamaan hak tetapi juga menyatakan fungsinya mempunyai arti bagi pembangunan dalam masyarakat di Indonesia. Secara umum alasan perempuan bekerja adalah untuk membantu ekonomi keluarga. Keadaan perekonomian yang semakin tidak menentu, harga-harga kebutuhan pokok yang semakin meningkat, pendapatan keluarga yang cenderung tidak meningkat akan berakibat pada terganggunya stabilitas perekonomian keluarga. Kondisi inilah yang mendorong ibu rumah tangga yang sebelumnya hanya menekuni sektor domestik (mengurus rumah tangga), kemudian ikut berpartisipasi di sektor publik dengan ikut serta menopang perekonomian keluarga. Sebagai tenaga kerja wanita dalam keluarga, umumnya ibu rumah tangga cenderung memilih bekerja di sektor informal. Hal ini dilakukan agar dapat membagi waktu antara pekerjaan dan keluarga. (Ervinawati dkk, 2015).

\section{B. Teori Pendapatan dan Pendapatan Keluarga}

Istilah pendapatan dalam usahatani banyak dimunculkan dengan berbagai pengertian seperti gross output, hasil penjualan, pendapatan keluarga , keuntungan dan sebagainya. Pendapatan bersih usahatani (net farm income) lebih banyak digunakan dalam analisis pendapatan usahatani. Pendapatan bersih petani berupa jumlah produksi dikalikan harga dikurangi dengan biaya produksi (widodo, 2008).

Pendapatan merupakan selisih antara seluruh penerimaan dan seluruh pengeluaran (biaya produksi yang betulbetul dikeluarkan) dari berbagai cabang usahatani atau TR >TC. Bila untuk memperbesar pendapatan yaitu dengan memperbesar TR dan memperkecil TC. TR merupaka hasil perkalian antara output (Y) dengan harga output TR = Y. Py. TR semakin

besar apabila Y semakin besar. Besarnya Y sangat berpengaruh oleh pemakaian faktor input, keadaan tanah, dan keadaan kondisi lingkungan sekitarnya. Selain itu, untuk memperbesar pendapatan dapat dengan memperkecil total biaya (TC). Total cost (TC) semakin kecil apabila rata-rata biaya persatuan output mengecil, hal ini dapat terjadi karena harga input menurun atau pemakaian input lebih efisien (Bishop dan Toussain dalam Leni, 2010).

Pendapatan yang dihitung adalah pendapatan atas biaya tunai yaitu selisih antara penerimaan tunai dengan biaya tunai yang dikeluarkan. penerimaan tunai adalah nilai uang yang diterima dari penjualan produk, sedangkan biaya tunai adalah jumlah yang dibayarkan untuk pembelian barang dan jasa. Biaya tunai juga diartikan sebagai biaya yang dikeluarkan untuk pembayaran kas yang dikenal dengan biaya eksplisit antara lain upah yang dibayarkan, pembayaran untuk berbagai bahan yang digunakan, biaya sarana umum dan biaya lainnya, sedangkan biaya implisit merupakan biaya yang tidak melibatkan pengeluaran kas atau berkaitan dengan setiap keputusan yang sulit dihitung (Soekartawi, 2003).

Kontribusi pendapatan pada satu jenis kegiatan terhadap total pendapatan rumah tangga tergantung pada produktivitas faktor produksi yang digunakan dari jenis kegiatan yang bersangkutan. Stabilitas pendapatan rumah tangga cenderung dipengaruhi oleh sumber pendapatan. Jenis-jenis pendapatan yang berasal dari luar sektor pertanian umumnya tidak terkait dengan musim dan dapat dilakukan setiap saat sepanjang tahun (Nurmanaf, 2006). 
Pendapatan keluarga merupakan balas karya atau jasa atau imbalan yang diperoleh karena sumbangan yang diberikan dalam kegiatan produksi". Secara konkritnya pendapatan keluarga berasal dari :

1. Usaha itu sendiri : misalnya berdagang, bertani, membuka usaha sebagai wiraswastawan.

2. Bekerja pada orang lain : misalnya sebagai pegawai negeri atau karyawan.

3. Hasil dari pemilihan : misalnya tanah yang disewakan dan lain-lain. pendapatan bisa berupa uang maupun barang misal berupa santunan baik berupa beras, fasilitas perumahan dan lain-lain. pada umumnya pendapatan manusia terdiri dari pendapatan nominal berupa uang dan pendapatan riil berupa barang (T.Gilarso dalam Kharisun, 2014).

\section{Ekonomi Islam}

Ekonomi Islam adalah sekumpulan dasar-dasar ekonomi yang berdasarkan Al-Quran dan Sunnah yang merupakan bagian perekonomian yang didirikan di atas landasan dasar-dasar tersebut sesuai dengan lingkungan dan masa. Dalam ekonomi Islam, berbagai jenis sumber daya dipandang sebagai pemberian atau titipan Tuhan kepada manusia. Manusia harus memanfaatkan seefisien dan seoptimal mungkin dalam produksi guna memenuhi kesejahteraan bersama yaitu untuk dirinya sendiri dan untuk orang lain (Lubis dalam Leni 2016).

Ekonomi Islam adalah ilmu yang mempelajari segala perilaku manusia dalam memenuhi kebutuhan hidupnya dengan tujuan memperoleh falah (kedamaian dan kesejahteraan duniaakhirat) atau pengetahuan dan aplikasi ajaran-ajaran dan aturan-aturan syari'ah yang mencegah ketidakadilan dalam pencarian dan pengeluaran sumbersumber daya, guna memberikan kepuasan bagi manusia dan memungkinkan mereka melaksanakan kewajiban-kewajiban mereka terhadap Allah dan masyarakat (Juniarti, 2011).

Islam dengan kitab suci al-Qur'an dan melalui Rasulullah SAW telah hadir secara ideal dengan gagasan besar mengajarkan prinsip dasar kemanusiaan, perlindungan hak azasi manusia dan kesederajatan serta mengajarkan setiap muslim untuk bekerja dan berusaha memakmurkan dunia, kebebasan mencari rizki sesuai dengan ketentuan dan norma syariat agama serta perintah mengerjakan amal shaleh yang bermanfaat bagi orang lain. Konsekuensi dari kewajiban ini adalah bahwa setiap manusia berhak untuk bekerja mendapatkan pekerjaan (Fuad, 2010).

Sebagaimana Firman Allah SWT dalam surat Ali-Imran ayat 195 berikut :

Artinya : "Sesungguhnya Aku tidak menyia-nyiakan amal orang-orang yang beramal di antara kamu baik laki-laki atau perempuan, (karena) sebagian kamu adalah keturunan dari sebagian yang lain. Maka orang-orang yang berhijrah, yang diusir dari kampung halamannya, yang disakiti pada jalan-Ku, yang berperang dan yang dibunuh, pastilah akan Ku-hapuskan kesalahan-kesalahan mereka dan pastilah aku masukkan mereka ke dalam surga yang mengalir sungai-sungai di bawahnya, sebagai pahala disisi Allah. Dan Allah pada sisi-Nya pahala yang baik “. (Depag RI, Al-Quran dan Terjemahan, 2002). Dari ayat diatas, dapat beberapa mufassirin menyimpulkan bahwa manusia, baik laki-laki maupun perempuan diciptakan Allah SWT untuk melakukan aktivitas pekerjaannya dan merupakan bagian dari amal saleh. Dengan bekerja maka seseorang akan dapat memenuhi kebutuhan hidupnya baik secara jasmani maupun rohani. Islam mengajarkan adanya kewajiban untuk bekerja sekaligus hak untuk mendapatkan pekerjaan yang dapat berlaku baik laki-laki maupun perempuan. Manusia dituntut untuk memperjuangkan kebutuhan hidup, 
seperti sandang, pangan, papan dan kesehatan.

\section{METODE PENELITIAN}

\section{A. Lokasi, Objek dan Ruang Lingkup Penelitian}

Penelitian ini dilakukan di Kelurahan Wawonggole Kecamatan Unaaha Kabupaten Konawe. Penentuan daerah penelitian ini dilakukan secara sengaja (purposive sampling) dengan pertimbangan bahwa di Kelurahan Wawonggole banyak terdapat wanita atau ibu rumah tangga yang bekerja sebagai penjual kue tradisioal dalam upaya untuk meningkatkan pendapatan keluarganya. Dimana rata-rata profesinya suaminya adalah petani. Objek penelitian ini adalah seluruh perempuan yang bekerja dalam usaha menjual jajanan kue tradisional. Ruang lingkup penelitian dibatasi pada partisipasi wanita penjual kue tradisional dalam meningkatkan pendapatan keluarga menurut perspektif ekonomi Islam dari di Kelurahan Wawonggole Kecamatan Unaaha Kabupaten Konawe.

\section{B. Metode dan Teknik Pengumpulan Data \\ Dalam penulisan ini menggunakan} metode deskriptif, yaitu penulisan yang memusatkan diri pada pemecahan masalah yang aktual dan berusaha mendeskripsi serta menginterpretasi mengenai kondisi atau hubungan yang ada. Jenis data yang dibutuhkan dalam penelitian ini meliputi data primer dan data sekunder. Data primer di peroleh data yang diperoleh langsung melalui pembagian kuesioner kepada responden dan dengan cara wawancara langsung dengan responden yang dijadikan sampel. Sedangkan data sekunder di peroleh dari literatur yang terkait dengan penelitian ini, baik instansi pemerintah maupun perpustakaan.

Metode pengumpulan data yang digunakan dalam penelitian ini adalah :
1. Observasi, yaitu pengumpulan data yang dilakukan melalui pengamatan secara langsung terhadap berbagai aktivitas ibu rumah tangga pembuat makanan olahan dari pangan dan kondisi lokasi penelitian.

2. Wawancara, yaitu pengumpulan data yang dilakukan melalui wawancara langsung dengan perempuan/ibu rumah tangga yang melakukan usaha membuat makanan tradisional dan menjualnya.

3. Kuisioner, yaitu pengumpulan data yang dilakukan dengan menggunakan daftar-daftar pertanyaan yang telah disediakan kepada perempuan/ibu rumah tangga penjual makanan tradisional.

\section{Analisis Data}

1. Untuk mengetahui besarnya kontribusi pendapatan wanita penjual kue tradisional terhadap total pendapatan keluarga digunakan rumus sebagai berikut :

$\mathrm{P}=\underline{\text { Pdistri }} \times 100 \%$

Pdk

Keterangan :

$\begin{array}{lll}\mathrm{P} & =\text { Kontribusi pendapatan } \\ & & \text { ibu rumah tangga }(\%) \\ \text { Pdistri } & =\text { Pendapatan ibu rumah } \\ & & \text { tangga/istri (Rp) } \\ \text { Pdk } & =\text { Pendapatan keluarga (Rp) }\end{array}$

Total pendapatan keluarga dihitung dengan menjumlahkan pendapatan semua anggota rumah tangga, yaitu :

Pdk = Pdkistri + Pdsuami

Keterangan :

Pdk =Pendapatan keluarga (Rp)

Pdsuami =Pendapatan total suami (Rp)

Pdistri=Pendapatan ibu rumah tangga (Rp)

Untuk mengetahui besarnya pendapatan diperoleh dengan cara mengurangkan total penerimaan dengan total biaya, dengan rumus : 


\begin{tabular}{|c|c|}
\hline NR & $=\mathrm{TR}-\mathrm{TC}$ \\
\hline NR & $=T R-(T V C+T F C)$ \\
\hline NR & $=\mathrm{Py} \cdot \mathrm{Q}-(\mathrm{TVC}+\mathrm{TFC})$ \\
\hline \multicolumn{2}{|c|}{ Keterangan: } \\
\hline NR & $=$ Net Revenue/ Pendapatan \\
\hline $\mathrm{TR}$ & $\begin{aligned}= & \text { Total Revenue/ Penerimaan } \\
& \text { Total }\end{aligned}$ \\
\hline TC & $=$ Total Cost $/$ Biaya Total \\
\hline TFC & $\begin{aligned}= & \text { Total Fixed Cost } / \text { Biaya } \\
& \text { Tetap Total }\end{aligned}$ \\
\hline TVC & $\begin{aligned}= & \text { Total Variable Cost } / \text { Biaya } \\
& \text { Variabel }\end{aligned}$ \\
\hline \multicolumn{2}{|l|}{ Total } \\
\hline Py & $=$ Harga output \\
\hline & $=$ Jumlah output \\
\hline
\end{tabular}

2. Untuk menganalisis tujuan kedua mengenai motivasi wanita penjual kue tradisional melakukan pekerjaan menjual kue tradisional dan tujuan ketiga tentang partisipasi wanita penjual kue tradisional dalam meningkatkan pendapatan keluarga menurut perspektif ekonomi Islam. menggunakan metode deskriptif kualitatif kemudian diperoleh kesimpulan dari permasalahan penelitian ini.

\section{HASIL PENELITIAN DAN PEMBAHASAN}

\section{A. Keadaan Umum Responden}

1. Umur

Umur merupakan salah satu faktor yang mempengaruhi perilaku dalam melakukan atau mengambil keputusan dan dapat bekerja secara optimal serta produktif. Seiring dengan perkembangan waktu, umur manusia akan mengalami perubahan dalam hal ini penambahan usia yang dapat mengakibatkan turunnya tingkat produktifitas seseorang dalam bekerja.
Tabel 1. Keadaan Responden Menurut Kelompok Umur di Kecamatan Unaaha Kelurahan Wawonggole, Tahun 2017.

\begin{tabular}{|c|l|c|c|}
\hline No. & \multicolumn{1}{|c|}{$\begin{array}{c}\text { Umur } \\
\text { (Tahun) }\end{array}$} & $\begin{array}{c}\text { Jumlah } \\
\text { Jiwa) }\end{array}$ & $\begin{array}{c}\text { Persentase } \\
\text { (\%) }\end{array}$ \\
\hline 1. & $1-15$ & - & - \\
2. & (belum & 9 & 100 \\
3. & produktif & - & - \\
& $16-50$ \\
(produktif) & & \\
& $\begin{array}{l}\text { (k0 } 50 \\
\text { (kurang } \\
\text { produktif) }\end{array}$ & & \\
\hline \multicolumn{2}{|c|}{ Jumlah } & 9 & 100 \\
\hline
\end{tabular}

Sumber: Data Primer Setelah Diolah, Tahun 2017.

2. Tingkat Pendidikan

Semakin tinggi pendidikan seseorang semakin mampu dalam menerima suatu informasi terutama dalam mengembangkan usahanya. Untuk mengetahui jenis tingkat pendidikan pengusaha responden dilokasi penelitian dilihat pada tabel berikut.

Tabel 2. Keadaan Responden Menurut Tingkat Pendidikan di Kelurahan Wawonggole Kecamatan Unaaha, Tahun 2017.

\begin{tabular}{|c|l|c|c|}
\hline No. & $\begin{array}{c}\text { Tingkat } \\
\text { Pendidikan }\end{array}$ & $\begin{array}{c}\text { Jumlah } \\
\text { (Jiwa) }\end{array}$ & $\begin{array}{c}\text { Persentase } \\
\text { (\%) }\end{array}$ \\
\hline 1. & SD & 1 & 11,11 \\
2. & SMP & 6 & 66,67 \\
3. & SMA & 2 & 22,22 \\
\hline & Jumlah & 9 & 100 \\
\hline
\end{tabular}

Sumber: Data Primer Setelah Diolah, Tahun 2017.

3. Pengalaman Berusaha

Pengalaman usaha dikatakan cukup apabila telah menggeluti bidang pekerjaan berusaha selama 5-10 tahun sedangkan 10 tahun ke atas dikategorikan berpengalaman dan kurang dari 5 tahun dikategorikan kurang berpengalaman. 
Tabel 3. Keadaan Responden Berdasarkan Pengalaman Berusaha Di Kelurahan Wawonggole Kecamatan Unaaha, Tahun 2017.

\begin{tabular}{|c|l|c|c|}
\hline $\begin{array}{c}\text { N } \\
\text { o. }\end{array}$ & $\begin{array}{c}\text { Pengalaman } \\
\text { Usaha } \\
\text { (Tahun) }\end{array}$ & $\begin{array}{c}\text { Jumla } \\
\text { h } \\
\text { (Jiwa) }\end{array}$ & $\begin{array}{c}\text { Persent } \\
\text { ase (\%) }\end{array}$ \\
\hline 1. & $<5$ & 2 & 22,22 \\
2. & $\begin{array}{l}\text { (kurangberp } \\
\text { engalaman) } \\
\text { 5-10 (cukup } \\
\text { berpengalam } \\
\text { an) }\end{array}$ & 7 & 77,78 \\
\hline \multicolumn{2}{|l|}{ Jumlah } & 9 & 100 \\
\hline
\end{tabular}

Sumber: Data Primer Setelah Diolah, Tahun 2017.

4. Jumlah Tanggungan Keluarga Jumlah tanggungan keluarga responden di Kelurahan Wawonggole Kecamatan Unaaha berkisar antara 1-5 orang. Untuk mengetahui lebih jelasnya jumlah tanggungan keluarga responden di lokasi pengusaha, dapat dilihat pada tabel 4.

Tabel 4. Keadaan Responden Berdasarkan Jumlah Tanggungan Keluarga

Di Kelurahan Wawonggole Kecamatan Unaaha, Tahun 2017.

\begin{tabular}{|c|l|c|c|}
\hline No. & $\begin{array}{c}\text { Jumlah } \\
\text { Keluarga }\end{array}$ & $\begin{array}{c}\text { Jumlah } \\
\text { (Jiwa) }\end{array}$ & $\begin{array}{c}\text { Persentase } \\
(\%)\end{array}$ \\
\hline l. & $\begin{array}{l}1-6 \\
\text { 2. }\end{array}$ & 9 & 100 \\
\hline \multicolumn{2}{|c|}{ Jumlah } & 9 & 100 \\
\hline
\end{tabular}

Sumber: Data Primer Setelah Diolah, Tahun 2017.

\section{B. Analisis Pendapatan}

Berdasarkan hasil penelitian besarnya biaya, penerimaan dan pendapatan dapat dilihat pada tabel berikut.
Tabel 5. Besarnya Biaya, Penerimaan dan Pendapatan responden Di Kelurahan Wawonggole Kecamatan Unaaha, Tahun 2017.

\begin{tabular}{|c|l|c|}
\hline No. & \multicolumn{1}{|c|}{ Uraian } & Nilai (Rp) \\
\hline l. & Biaya Variabel & 3.050 .000 \\
2. & Biaya Tetap & 600.000 \\
3. & Total Biaya & 3.650 .000 \\
4. & Penerimaan & 10.850 .000 \\
5. & Pendapatan & 7.200 .000 \\
\hline
\end{tabular}

Sumber: Data Primer Setelah Diolah, Tahun 2017.

Dari hasil penelitian besarnya total biaya tetap sebesar Rp. 600.000 atau dengan rata-rata Rp. 120.000 sedangkan total biaya variabel sebesar Rp. 3.050 .000 atau dengan rata-rata Rp. 610.000 sehingga Jumlah total dari biaya yang dikeluarkan dalam usaha pembuatan makanan olahan pangan di Kelurahan Wawonggole dalam 1 bulan adalah sebesar Rp. 3.650.000 atau dengan ratarata Rp. 730.000 dan untuk total penerimaan adalah sebesar Rp. 10.850.000 atau dengan rata-rata Rp. 2.170.000. Dilihat dari selisih penerimaan dan biaya yang dikeluarkan menunjukkan bahwa usaha pembuatan makanan kue tradisional di Kelurahan Wawonggole Kecamatan Unaaha Kabupaten Konawe memberikan pendapatan yang besar yaitu sebesar Rp. 7.200.000 atau dengan ratarata sebesar Rp. 1.430.000.

\section{Kontribusi Pendapatan Terhadap Pendapatan Keluarga \\ Dalam penelitian ini pendapatan} keluarga berasal dari tiga sumber, yaitu dari kepala keluarga (ayah), dari responden (membuat makanan olahan maupun dari pekerjaan lain), dan anak yang sudah bekerja.

Total pendapatan keluarga pembuat makanan olahan pangan dihitung dengan menjumlahkan pendapatan semua anggota rumah tangga, yaitu :

$$
\begin{array}{ll}
\text { I } & =I_{1}+I_{2}+I_{3} \\
\text { I } & =\text { Rp. } 7.200 .000+\text { Rp. } 12.000 .000+
\end{array}
$$


Rp. 3.700 .000

I $\quad=$ Rp. 22.900 .000

Berdasarkan hasil penelitian besarnya pendapatan wanita pembuat makanan olahan pangan adalah sebesar Rp. 7.200 .000 atau dengan rata-rata sebesar Rp. 1.435.000, pendapatan suami adalah sebesar Rp. 12.000 .000 atau dengan rata-rata sebesar Rp. 2.400.000, sedangkan pendapatan anggota keluarga lainnya adalah sebesar Rp. 3.700 .000 atau rata-rata Rp. 740.000. Dari uraian tersebut dapat diketahui total pendapatan keluarga wanita pembuat makanan olahan bahan pangan di Kelurahan Wawonggole Kecamatan Unaaha Kabupaten Konawe adalah sebesar Rp. 22.900.000 atau rata-rata Rp. 4.275.000.

Setelah mengetahui besar masingmasing pendapatan yang diperoleh keluarga wanita pembuat makanan olahan pangan maka dapat diketahui total pendapatan keluarga selama satu bulan serta kontribusi pendapatan wanita tani pembuat atap rumbia terhadap total pendapatan keluarga di Kelurahan Wawonggole Kecamatan Unaaha Kabupaten Konawe. Untuk lebih jelasnya pendapatan istri, pendapatan suami, pendapatan keluarga lain (anak) dan kontribusi pendapatan wanita pembuat makanan olahan pangan terhadap total pendapatan keluarga di Kelurahan Wawonggole Kecamatan Unaaha Kabupaten Konawe dapat dilihat pada Tabel 6.
Tabel 6. Kontribusi Pendapatan Wanita

Pembuat Makanan Olahan Pangan

Terhadap Total Pendapatan Keluarga di Kelurahan Wawonggole

\begin{tabular}{|c|l|c|}
\hline No. & \multicolumn{1}{|c|}{ Uraian } & Nilai (Rp) \\
\hline l. & Pendapatan & 7.200 .000 \\
2. & Wanita/istri & 12.000 .000 \\
3. & Pendapatan & 3.700 .000 \\
4. & Suami & 22.900 .000 \\
5. & Pendapatan & 31,44 \\
& Keluarga Lain & \\
& Total Pendapatan & \\
& Keluarga & \\
& Kontribusi & \\
& Terhadap & \\
& Pendapatan & \\
& Keluarga (\%) & \\
\hline
\end{tabular}

Sumber: Data Primer Setelah Diolah, Tahun 2017

Berdasarkan tabel 6 menunjukkan bahwa kontribusi pendapatan usaha wanita pembuat makanan olahan bahan pangan terhadap total pendapatan keluarga yaitu 31,44 \%. Hal ini menunjukkan usaha menjual makanan kue tradisional di Kelurahan Wawonggole Kecamatan Unaaha Kabupaten Konawe dapat dikatakan sebagai usaha sampingan atau tambahan yang berpotensi untuk dikembangkan dalam upaya meningkatkan pendapatan keluarga dan tingkat kesejahteraannya.

\section{Motivasi Wanita Untuk Bekerja}

Motivasi merupakan proses pemberian dorongan kepada seseorang untuk melakukan sesuatu, sehingga tujuan yang diingainkan dapat tercapai (Sulistiyani dan Rosidah, 2003). Motivasi kerja merupakan motivasi yang terjadi pada situasi dan lingkungan kerja yang terdapat pada suatu organisasi atau lembaga. Pada dasarnya manusia selalu menginginkan hal baik-baik saja, sehingga daya pendorong atau penggerak yang memotivasi semngat kerjanya tergantung dari harapan yang diperoleh mendatang jika harapan itu menjadi kenyataan maka 
seseorang akan cenderung meningkatkan motivasi kerjanya.

Salah satu konsep motivasi adalah untuk menggambarkan hubungan antara harapan dan tujuan. Setiap orang ingin dapat mencapai sesuatu atau tujuan dalam kegiatan-kegiatannya. Hasil penelitian menunjukkan responden mempunyai jawaban yang semuanya hampir sama tentang motivasi bekerja. Motivasi dalam penelitian ini dilihat dari dua sisi : ekonomi dan sosial. Menambah pendapatan keluarga merupakan motivasi ekonomi yang dinyatakan oleh 6 orang responden $(66,67 \%)$, sedangkan sisanya menyatakan alasan motivasi sosial, yaitu: sebesar 3 orang responden $(33,33 \%)$ menyatakan untuk mengisi waktu luang agar menghasilkan sesuatu yang bernilai ekonomis.

Pada umumnya motivasi bekerja kebanyakan tenaga kerja wanita adalah membantu menghidupi keluarga. Akan tetapi, motivasi itu juga mempunyai makna khusus karena memungkinkan memiliki otonomi keuangan, agar tidak selalu tergantung pendapatan suami. Terdapat hal yang menegaskan bahwa motivasi pribadi yang mendorong seorang perempuan yang telah berkeluarga untuk bekerja sehingga harus meningglkan rumah tangga, yaitu meliputi (Mudzhar, 2001).

Dihubungkan dengan tingkat pendidikan seseorang, maka tingkat pendidikan responden yang rata-rata tergolong cukup berpendidikan. Hal ini menunjukkan bahwa responden mempunyai kesadaran yang tinggi untuk berusaha meningkatkan perekonomian keluarga melalui kegiatan yang lebih bermanfaat yaitu bekerja, tanpa mengabaikan tugas sebagai ibu rumah tangga.

Hasil penelitian menunjukkan sebagian besar responden 5 orang responden $(55,56 \%)$ tidak mengalami hambatan baik dari aspek ekonomi dan sosial. Hal ini dikarenakan pekerjaan membuat makanan kue tradisional dikerjakan setelah selesai melakukan pekerjaan non ekonomis mengurus rumah tangga. Hanya sebagian kecil responden yang mempunyai hambatan dalam pembuatan makanan kue tradisional ini, hambatan ekonomis seperti adanya pesaing yang membuat makanan kue tradisional sejenis (onde-onde, teripang, sanggara banda, dadar, panada, jalang kote, doko-doko, lapisi, burasa, dan roti pawa) di dinyatakan oleh 4 orang responden (44,44\%). Hambatan lain yaitu hambatan sosial dirasakan oleh responden yang kesulitan dalam membagi waktu untuk keluarga, kondisi ini dialami oleh responden yang mempunyai pekerjaan lain disamping kegiatan membuat makanan olahan kue tradisional.

Berdasarkan uraian diatas menunjukkan motivasi responden wanita atau ibu rumah tangga untuk membuat dan menjual kue tradisional adalah untuk menambah pendapatan keluarga, untuk mengisi waktu luang dengan kegiatan positif dan juga karena membuat makanan olahan kue tradisonal yang berbahan dasar bahan pangan (seperti beras, tepung beras, ubi kayu, sayursayuran dan lain-lain) lebih mudah dan praktis serta mudah untuk diolah dan disajikan karena hal itu lebih banyak disukai dibandingkan dengan makanan siap saji.

Pekerjaan sampingan yang dilakukan wanita penjual kue tradisional yaitu sesuatu pekerjaan yang mampu menimbulkan penambahan sumber pendapatan keluarga melalui usaha jualan kue tradisional. Pekerjaan tersebut menjadi pekerjaan rutin sepajang bulan dalam setahun, sehingga penghasilan dari pekerjaan tersebut juga dapat dihitung dalam waktu bulanan. 


\section{E. Partisipasi Wanita Penjual Kue Tradisional Dalam Meningkatkan Pendapatan Keluarga Menurut Perspektif Ekonomi Islam}

Fenomena kemiskinan di Indonesia muncul tidak hanya pada dimensi ekonomi atau material saja. Kemiskinan juga menyentuh dimensi lain yaitu sosial budaya sehinggamunculah istilah cultural poverty yang dikemukakan oleh Oscar Lewis dalam teorinya. Faktor kultural secara khusus sering menunjuk pada konsep "kemiskinan kultural" atau "budaya kemiskinan" yang menghubungkan kemiskinan dengan kebiasaan hidup atau mentalitas. Hal ini muncul sebagai akibat adanya Sikapsikap "negatif" yang dianut oleh orangorang miskin seperti malas, fatalisme atau menyerah pada nasib, tidak memiliki jiwa wirausaha, dan kurang menghormati etos kerja (Suharto, 2009).

Wanita yang telah berumah tangga akan mencurahkan waktunya untuk kegiatan rumah tangga, yaitu kegiatan ekonomi dan kegiatan non ekonomi. Curahan waktu yang diberikan responden pada kegiatan non ekonomi yang dimaksud disini merupakan salah satu kewajiban istri dirumah terhadap keluarga dengan harapan tidak mendapatkan imbalan seperti memasak, mencuci, mengasuh anak dan lain sebagainya. Pekerjaan-pekerjaan didalam rumah tangga inilah yang menjadi tanggung jawab besar sebagai istri, dimana seorang istri lebih memperhatikan dan lebih tekun terhadap pekerjaan tersebut. Maka dari itu peran seorang wanita sangatlah besar baik didalam kegiatan mencari nafkah maupun kegiatan sebagai ibu rumah tangga.

Partisipasi yang diberikan wanita atau istri terhadap keluarga yakni keikutsertaan wanita (istri) dalam sesuatu, baik dalam bentuk partisipasi pemikiran atau materi.Alasan utama wanita/istri ikut berkontribusi sematamata hanya ingin membantu perekonomian keluarga, meringankan beban suami agar tidak terlalu berat dalam hal keuangan.

Untuk meningkatkan pendapatan keluarga dalam rangka untuk menunjang peningkatan ekonomi keluarga, maka wanita (ibu-ibu rumah tangga) melakukan pekerjaan sebagai penjual kue tradisional di rumah untuk dijajakan kepada pembeli dengan dijual di rumah, ke warung, kantin sekolah, dijual kepasar atau untuk pesanan jumlah besar yang digunakan untuk acara perkawinan, arisan, maupun ibadah keagamaan.

Peran wanita sebagai ibu rumah tangga yang bekerja sebagai pedagang atau penjual kue tradisional (onde-onde, teripang, sanggara banda, dadar, panada, jalang kote, doko-doko, lapisi, burasa, dan roti pawa), akan dapat meningkatkan pendapatan keluarga. Hal ini terlihat pada tingginya presentasi jawaban ibu-ibu rumah tangga yang bekerja sebagai penjual makanan kue tradisional, maka pendapatan keluarganya meningkat, pendapatan keluarganya cenderung stabil atau mencukupi kebutuhan keluarganya.

Partisipasi wanita dalam memberkan kontribusi pendapatan tergolong cukup membantu keuangan keluarga walaupun persentasenya hanya $31,44 \%$ pada total pendapatan keluarga hanya sedikit bila dibandingkan dengan kontribusi suami dalam pendapatan rumah tangga. Dimana kontribusi pendapatan suami sebesar 52,40 \% dan kontribusi pendapatan dari keluarga lain seperti anak adalah sebesar 16,16 \%. Pendapatan suami pada umumnya mempunyai kontribusi pendapatan paling besar diantara anggota rumah tangga yang lain karena suami mempunyai kewajiban mencari nafkah. Selain itu wanita ini selaku sebagai isteri kebutuhan hidupnya ditanggung oleh suaminya sehingga ia tidak berkewajiban mencari nafkah.

Dalam Islam bekerja dinilai sebagai kebaikan, dan kemalasan dinilai sebagai kejahatan. Nabi berkata: ibadah yang 
paling baik adalah bekerja, dan pada saat yang sama bekerja merupakan hak sekaligus kewajiban. Pada suatu hari Rasulullah Saw menegur seseorang yang malas dan meminta-minta, seraya menunjukan kepadanya jalan kearah yang produktif. Rasulullah meminta orang tersebut menjual asset yang dimilikinya dan menyisihkan hasil penjualannya untuk modal membeli alat (kapak) untuk mencari kayu di tempat bebas dan menjualnya ke pasar. Beliaupun memonitor kinerjanya untuk memastikan bahwa ia telah mengubah nasibnya kearah kerja yang produktif (Nasution ddk, 2007),

Islam telah memposisikan perempuan di tempat mulia sesuai dengan kodratnya. Dr. Yusuf Qardhawi pernah mengatakan, "Perempuan memegang peranan penting dalam kehidupan keluarga dan masyarakat“. Jadi, mana mungkin keluarga dan masyarakat itu baik jika perempuannya tidak baik ( Qordhawi, 2013).

Al-Qur'an telah memberikan pandangan terhadap keberadaan dan kedudukan perempuan. Islam sangat memberikan kesempatan kepada perempuan untuk mengembangkan dirinya sebagai sumber daya manusia di tengah-tengah masyarakat dan telah secara jelas mengajarkan adanya persamaan antara manusia laki-laki dan perempuan maupun antar bangsa, suku dan keturunan. Yang membedakan mereka terutama adalah tingkat ketaqwaannya (Umar, 2014).

Allah SWT berfirman dalam AlQur'an dalam QS. Al-Hujurat :14 berikut ini.

Artinya : "Hai manusia, Sesungguhnya Kami menciptakan kamu dari seorang laki-laki dan seorang perempuan dan menjadikan kamu berbangsa-bangsa dan bersuku-suku supaya kamu saling kenal-mengenal. Sesungguhnya orang yang paling mulia diantara kamu disisi Allah ialah orang yang paling taqwa diantara kamu. Sesungguhnya Allah Maha mengetahui lagi Maha Mengenal". (Depag RI : Al-Qur'an dan Terjemahan, 2002).

Islam dengan kitab suci al-Qur'an dan melalui Rasulullah SAW telah hadir secara ideal dengan gagasan besar mengajarkan prinsip dasar kemanusiaan, perlindungan hak azasi manusia dan kesederajatan serta mengajarkan setiap muslim untuk bekerja dan berusaha memakmurkan dunia, kebebasan mencari rizki sesuai dengan ketentuan dan norma syariat agama serta perintah mengerjakan amal shaleh yang bermanfaat bagi orang lain. Konsekuensi dari kewajiban ini adalah bahwa setiap manusia berhak untuk bekerja mendapatkan pekerjaan (Fuad, 2010).

Didalam Islam tidak ada larangan bagi seorang perempuan untuk bekerja mencari nafkah maupun ikut membantu meningkatkan perekonomian keluarga selagi mendapat izin dari suami. Bahkan Islam melarang kepada seluruh umat muslim untuk berpangku tangan atau meminta-minta sebagai pengemis, gelandangan dan lain-lain selagi umat tersebut masih mampu untuk berusaha. Allah SWT berfirman dalam surat AlJumua'ah ayat 10 berikut ini.

Artinya : "Apabila telah ditunaikan shalat, Maka bertebaranlah kamu di muka bumi dan carilah karunia Allah dan ingatlah Allah banyak-banyak supaya kamu beruntung". (Depag RI : Al-Qur'an dan Terjemahan, 2002).

Keikutsertaan kaum wanita berpartisipasi di bidang pekerjaan (bekerja) dalam upaya meningkatkan pendapatan keluarganya, dalam Islam diwajibkan jika berada dalam dua kondisi, pertama jika seorang perempuan harus menanggung biaya sendiri beserta keluarga pada saat orang menanggungnya tidak ada atau sudah tidak berdaya atau apabila pendapatan suami tidak dapat mencukupi kebutuhan yang dibutuhkan. Kedua, dalam kondisi perempuan 
dianggap fardhu kifayah untuk melakukan suatu pekerjaan yang dapat membantu terjaganya eksistensi suatu masyarakat muslim. Dalam kondisi seperti ini, seorang perempuan harus bekerja (berusaha) sedapat mungkin menyeimbangkan kewajiban dengan tanggung jawabnya terhadap rumah tangga dan anak-anak.

Partisipasi kaum wanita penjual kue tradisional di Kelurahan Wawonggole Kecamatan Unaaha Kabupaten Konawe merupakan suatu usaha yang dilakukan Ibu Rumah Tangga dalam meningkatkan pendapatan keluarganya dan bisa membantu kebutuhan ekonomi. Usaha yang dilakukan oleh wanita penjual kue tradisional dalam meningkatkan kesejahteraan keluarga merupakan usaha yang baik dan sejalan dengan syari'at Islam karena dilakukan dengan usaha dan niat yang baik, tidak adanya pelanggaran syari'at istri tidak meninggalkan kewajibannya dalam mengatur rumah tangga untuk membantu suaminya.

Manusia, baik laki-laki maupun perempuan diciptakan Allah SWT untuk melakukan aktivitas pekerjaannya dan merupakan bagian dari amal saleh sebagaimana dalam QS. Al-Imran ayat 195 dan QS. An-Nahl ayat 97. Dengan bekerja maka seseorang akan dapat memenuhi kebutuhan hidupnya baik secara jasmani maupun rohani. Islam mengajarkan adanya kewajiban untuk bekerja sekaligus hak untuk mendapatkan pekerjaan yang dapat berlaku baik lakilaki maupun perempuan. Manusia dituntut untuk memperjuangkan kebutuhan hidup, seperti sandang, pangan, papan dan kesehatan.

Dari penjelasan di atas, dapat diambil kesimpulan bahwa secara umum, usaha wanita sebagai penjual kue tradisional untuk membantu meningkatkan perekonomian keluarga boleh dilakukan karena tidak bertentangan dengan prinsip Ekonomi Islam.

\section{KESIMPULAN}

1. Berdasarkan hasil penelitian besarnya pendapatan wanita penjual kue tradisional adalah sebesar Rp. 7.200.000 atau dengan rata-rata sebesar Rp. 1.435.000, pendapatan suami adalah sebesar Rp. 12.000.000 atau dengan rata-rata sebesar $\mathrm{Rp}$. 2.400.000, sedangkan pendapatan anggota keluarga lainnya adalah sebesar Rp. 3.700.000 atau rata-rata Rp. 740.000. Dari uraian tersebut dapat diketahui total pendapatan keluarga wanita pembuat makanan olahan bahan pangan di Kelurahan Wawonggole Kecamatan Unaaha Kabupaten Konawe adalah sebesar Rp. 22.900.000 atau rata-rata Rp. 4.275.000.

Dengan kontribusi pendapatan usaha wanita penjual kue tradisional terhadap total pendapatan keluarga yaitu 31,44\%, kontribusi suami dalam pendapatan rumah tangga sebesar $52,40 \%$ dan kontribusi pendapatan dari keluarga lain seperti anak adalah sebesar $16,16 \%$.

2. Motivasi responden wanita atau ibu rumah tangga untuk membuat dan menjual kue tradisional adalah untuk menambah pendapatan keluarga dan untuk mengisi waktu luang dengan kegiatan positif.

3. Partisipasi kaum wanita penjual kue tradisional dalam upaya meningkatkan pendapatan keluarganya dan membantu kebutuhan ekonomi merupakan usaha yang baik dan sejalan dengan syari'at Islam karena dilakukan dengan usaha dan niat yang baik, selama istri tidak melakukan pelanggaran syari'at yaitu tidak meninggalkan kewajibannya dalam mengatur rumah tangga untuk membantu suaminya. secara umum, usaha wanita sebagai penjual kue 
tradisional untuk membantu meningkatkan perekonomian keluarga boleh dilakukan karena tidak bertentangan dengan prinsip Ekonomi Islam.

\section{DAFTAR PUSTAKA}

Dahlan,Juariyah. 1994. Wanita Karir, Jurnal IAIN Sunan Ampel Edisi XII, Surabaya.

Departemen Agama. 2002. Al-Quran dan Terjemahan. Semarang: PT. Toha Putra.

Ervinawati, Vivin, Fatmawati, Endang Indri L. 2015. Peranan Kelompok Wanita Tani Perpedesaan dalam Menunjang Pendapatan Keluarga (Di Dusun Beringin Desa Sungai Rengas Kecamatan SungaiKakap, Kabupaten Kubu Raya Provinsi Kalimantan Barat). Jurnal Tesis PMIS-UNTAN-PSS2015.

Fatmawati. 2011. Kontribusi curahan kerja wanita pada usaha peternakan kelinci, di Kelurahan Salokaraja, Kecamatan Lalabata, Kabupaten Soppeng. Skripsi Jurusan Sosial Ekonomi Peternakan, Fakultas Peternakan, Universitas Hasanuddin. Makassar.

Fuad, Ahmad Nur Fuad. 2010. Hak Asasi Manusia dalam Perspektif Islam. (Malang: Muhammadiyah) Jakarta timur.

Handayani, M.Th dan Ni Wayan Putu Artini. 2009. Kontribusi pendapatan ibu rumah tangga pembuat makanan olahan terhadap total pendapatan keluarga. Jurnal Kependudukan dan Pengembangan

Sumber Daya Manusia. Volume V No. 1 Juli 2009, hal. 7.
Juniarti, 2011. Efektifitas dan Efisiensi Pemasaran Meubel CV. Pasaman Rantau Jaya Industri Dumai Menurut Perspektif Ekonomi Islam. Skripsi Jurusan Ekonomi Islam UIN Sultan Syarif Kasim Riau. Pekan Baru.

Kharisun, Muhammad. 2014. Karakteristik dan Peran Istri Nelayan dalam Pendapatan Keluarga Nelayan Di Kota Pekalongan. Skripsi Fakultas Ekonomika dan Bisnis Universitas Diponegoro. Semarang.

Leni, Saleh. 2010. Produktivitas dan Efisiensi Usaha Tani Tanaman Padi Sawah Kabupaten Konawe Tesis Unpublished Universitas Gadjah Mada Pascasarjana Program Studi Ekonomi Pertanian Fakultas Pertanian. Yogyakarta.

Leni, Saleh. 2016. Perubahan Nilai Tukar Uang Menurut Perspektif Ekonomi Islam.

Jurnal Studi Ekonomi Islam dan Bisnis Islam Li Falah. Volume 1. Nomor 1. IAIN Kendari

Lestari, Endah., Imam Santoso., dan Rina Dwi Sulastri. 1997. Kontribusi Wanita dalam Agribisnis Gula Semut Di Kabupaten Blitar Propinsi Jawa Timur. Jurnal Penelitian Ilmu-Ilmu Sosial (Social Science) Volume 9 Nomor : 47-53. Lembaga Penelitian Universitas Brawijaya. Malang.

Majid, Fitria. 2012. Faktor-faktor Yang Mempengaruhi Keputusan Perempuan Berstatus Menikah Untuk Bekerja (Studi Kasus : Kota Semarang). Skripsi Fakultas Ekonomika dan Bisnis UNDIP. Semarang.

Mudzhar, H.M. Atho et al. 2001. Wanita dalam Masyarakat Indonesia Akses, 
Pemberdayaan dan Kesempatan.

Pustaka Pelajar. Yogyakarta.

Mursi, Abd. Hamid. 1996. Sumber Daya Manusia yang Produktif, Pendekatan AlQur'an dan Sain. Jakarta: Gema Insani Press.

Nasution, Mustafa Edwin ddk. 2007. Pengenalan Ekslusif Ekonomi Islam.Jakarta : Kencana.

Nugroho, Riant. 2008. Gender dan Adminstras Publik. Pustaka Pelajar.Yogyakarta.

Nurmanaf, A.Rozany. 2006. Peranan Sektor Luar Pertanian terhadap Kesempatan dan Pendapatan di Pedesaan Berbasis Lahan Kering. Jurnal SOCA vol 8. no.3. November 2008, hal 318-322.

Qordhawi $\quad$ Yusuf. 2013. http://media.isnet.org/islam/Qardha wi/Fatawa/PerananWanita.html. (6Februari2013.

Said, Muh. 2008. Pengantar Ekonomi Islam; Dasar- Dasar dan Pengembangan. Pekanbaru: Suska Press.

Sholahuddin, M. 2007. Azas-Azas Ekonomi Islam. Jakarta: PT.Raja Grafindo Perseda.

Sobary, Muhammad. 1999. Menakar Harga Wanita, Wanita Dalam Budaya Dominasi Simbolis dan Actual Kaum Lelaki. Penerbit Mizan : Bandung.

Soekartawi. 2003. Agribisnis Teori dan Aplikasinya. PT. Raja Grafindo Persada. Jakarta.

Sugiarti, Handayani. 2008. Konsep dan Teknik Penelitian Gender. Malang: UMM Malang.
Suharto, Edi. 2009. Membangun Masyarakat Memberdayakan Masyarakat. Bandung : PT Refika Aditama.

Sulistiyani, Ambar. T dan Rosidah. 2003. Manajemen Sumber Daya Manusia. Graha Ilmu. Yogyakarta.

Tasbichah, Ummi Luthfiyatut. 2015. Partisipasi Istri Nelayan Pandega Sebagai Pengupas Rajungan dalam Upaya Meningkatkan Pendapatan Keluarga Di Kelurahan Pacar Kecamatan Rembang Kabupaten Rembang. Skripsi Prodi Ekonomi Pembangunan Universitas Negeri Semarang. Semarang.

Utami Hari Dwi, Dewi Puji Rahayu, and Umi Wisapti Ningsih. 2012. Analisis Curahan Jam Kerja dan Sumbangan Pendapatan Tenaga Kerja Wanita Pada Usaha Penetasan Telur Itik. Journal University of Brawijaya. Malang.

Umar, Nasaruddin. 2014. "Perspektif Gender dalam Islam. Jurnal Pemikiran Islam Paramadina", dalam http://media.isnet.org/Islam/Parama dina/Jurnal/Jender3.html.

Widodo, Sri. 2008. Campur sari Agro Ekonomi, Liberty Yogyakarta.

Winardi. 2002. Motivasi dan Pemotivasian dalam Manajeman. Jakarta: PT.Grafindo Persada. 